$1-1-1924$

\title{
Amount of Carbon Dioxide Given Off by Eggs During Incubation
}

Horace Atwood

Charles Edward Weakley

Follow this and additional works at: https://researchrepository.wvu.edu/ wv_agricultural_and_forestry_experiment_station_bulletins

\section{Digital Commons Citation}

Atwood, Horace and Weakley, Charles Edward, "Amount of Carbon Dioxide Given Off by Eggs During Incubation" (1924). West Virginia Agricultural and Forestry Experiment Station Bulletins. 185.

https://researchrepository.wvu.edu/wv_agricultural_and_forestry_experiment_station_bulletins/185 @ WVU. It has been accepted for inclusion in West Virginia Agricultural and Forestry Experiment Station Bulletins by an authorized administrator of The Research Repository @ WVU. For more information, please contact ian.harmon@mail.wvu.edu. 


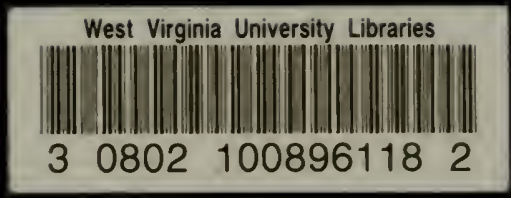


Digitized by the Internet Archive in 2010 with funding from

Lyrasis Members and Sloan Foundation 


\section{Aqricultural Experiment Station}

College of Agriculture, Jatest Yirginia Anibersity

HENRY G. KNIGHT, Director

Morgantown

\section{Amount of Garbon Dioxide Given Oif By Eggs During Incubation}

(Technical)

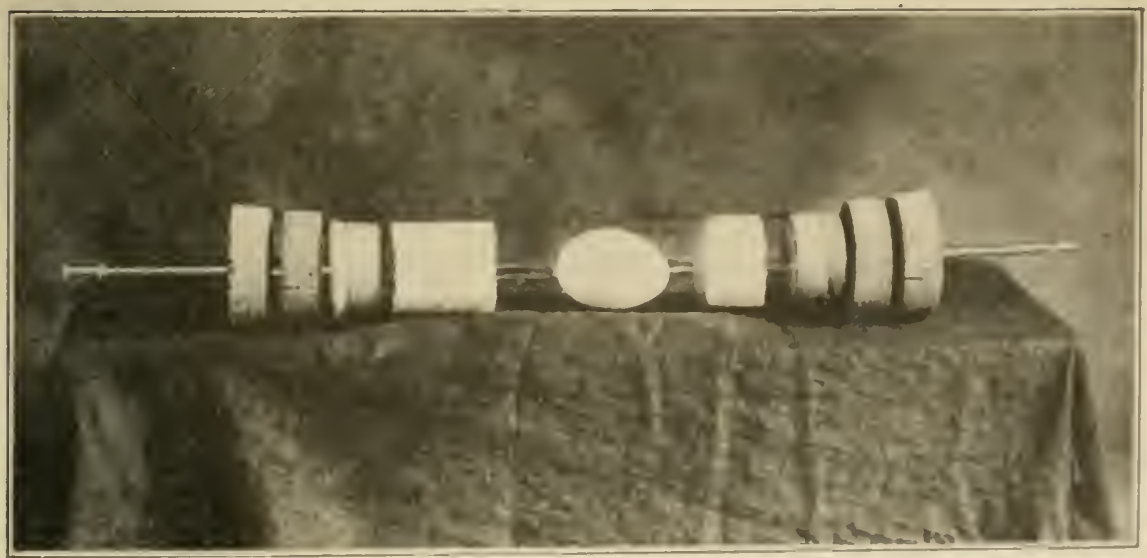

Fig. 1.-An Egg In A Glass Tube Ready for The Incubator.

I3y

HORACLA ATHO(ग)

CIIAIIES E. WEATLEY, Jr. 


\section{AGRIGULTURAL EXPERIMENT STATION STAFF}

FRANK B. TROTTER, A.M., LL.D.

President of the University GEORGE R. LYMAN, Ph.D. HENRY G. KNIGHT, Ph.D C. E. STOCKDALE, B.S. Agr. JOHN C. JOHNSTON Dean of the College of Agriculture Director of the Experiment Station Agricultural Editor AGRONOMY

R. J. Garber, Ph. D.

T. E. Odland, M. S.***

Agronomist

Assistant Agronomist

T. C. McIlvaine, M. S. $\ddagger$ Assistant Agronomist

K. S. Quisenberry, B. S. Junior Agronomist

ANIMAL HUSBANDRY

E. A. Livesay, M. S.

Animal Husbaudman

E. C. Stillwell, B. S. Junior Animal Husbandman

Chas. V. Wilson, B. S. Agr.

Junior Animal Husbandman

R. H. Tuckwiller, B. S. Agr.*

Assistant Animal Husbandman

\section{CHEMISTRY}

Henry G. Knight, Ph. D.

Chemist

Chas. E. Weakley, Jr.

F. B. Kunst, B. A.** Assistant Chemist

T. B. Leith, B. A.**

Assistant Chemist

T. J. Cochran, B. S.

Assistant Chemist Junior Clie:ist

\section{DAIRY HUSBANDRY}

Ernest L. Anthony, I.I. S. $\Lambda g r * * *$

Dairy Inusbandia!n

H. O. Henderson, M. S. Agr.

Associate Iniry Husband…"

Warren Gifford, B. S. A $₫$ r.

Assistant in Dairy IIusbanil.

G. M. Trout, B. S.

Junior Dairy Husbandn! 1

ENTOMOLOGY

L. M. Peairs, M. S.

W. E. Rumsey, B. S.**

Entomolog:

Assistant Entomolog:s

\section{FARM ECONOMICS}

A. J. Dadisman, M. S. Agr.

Associate Farm Econonis

J. H. Shaffer, B. S. Agr.

Junior Farm Economi

F. D. Cornell, B. S.***

Junior Farm Mechanician Chief Clerk

HORTICULTURE

M. J. Dorsey, Ph. D.

Horticulturist

H. L. Crane, M. S. Agr.

Associate Horticulturist

H. E. Knowlton, Ph. D.

Associate Horticulturist

K. C. Westover, B. S. Agr.

Assistant Horticulturist

Ernest Angelo, B. S. Agr.***

Junior Horticulturist

L. F. Sutton, B. S. Agr. $\dagger$

Assistant Horticulturist

Troy M. Currence, B. S. Agr.

Assistant in Horticulture

H. P. Sevy, B. S.

Assistant in Horticulture

\section{PLANT PATHOLOGY}

N. J. Giddings, Ph. D.

Plant Pathologist

Anthony Berg, B. S.***

Assistant Plant Pathologist

L. H. Leonian, Ph. D.

Assistant Plant Pathologist

E. C. Sherwood, M. S.

Assistant Plant Pathologist

POULTRY HUSBANDRY

lorace Atwood, M. S. Agr.

Poultry Husbandman

SOILS

D. P. Deatrick, Ph. D.

Associate Soil Technologist

P. C. Daughenbaugh

Assistant in Soil Technology

VETERINARY

C. $\Lambda$. Iueder, D. V. M. Veterinarian

- In co-operation with the U. S. Department of Agriculture, Washington, D. C. * In co-operation with the State Department of Agriculture, Charleston, W. Va.

In Co-operation with the Reymann Memorial Farms, Wardensville W. Va

tIn Charge of the Maggie Sub-Station, Maggie, W. Va. 


\section{Amount Of Carbon Dioxide Given Oif By Eggs During Incubation}

During incubation eggs give off moisture and carbon diuxide. The circulation of air through the incubation chamber is designed especially for the purpose of carrying away this moisture and carbun dioxide and for supplying oxygen to the developing embryos.

The total loss in weight of eggs thus occasioned during incubation has been studied by the senior anthor and the results published as Bulletin 73, West Virginia Agricultural lixperiment Station. The present publication deals only with the amount of carbon dioxide given off. The chenical work of this investigation has been done entirely by the junior author who also designed the apparatus cmployed.

\section{PREVIOUS WORK}

Practically all of the work reporter to date has been lased nuon the amount of carbon dioxide found in the air surrounding eggs hatched either in incubators or under hens. Brigham (1) reported that he found from 1.3 to 61 parts of carbon dioxide in 10.000 parts of air, in air drawn from the egg chamber of an inculator. Thom (2) determined the amount of carbon clioxide in inculaturs and under hens and found an arerage of 31.98 parts per 10.000 parts of air, in air drawn from under hens, and about one-hali as much in air from incubators. Dryden (3) found more carbun dioxide in the atr taken from under hens inculating fertile egrgs than in the air frum incubators. Iater he found $(t)$ that the hatch was not improved by increasing the amount of carbon clioxide present in the air in the inculuator. Edmond (5) determined the carlom diuxide in incubaturs and moler hens, and found that the amount gradually increased ats the inculontion progressed. Ender hens toward the cluse of the inculatimg period he found 22 parts in 10.000 parts of air, and in the air from incubators from + parts at the begiming of the hatch 40219.5 parts in 10,000 parts of air at the end. Lamsom and linmond (6) fommel that the amount of carbun dioxicle given off increased in fropmetion th the

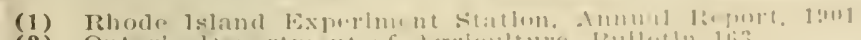

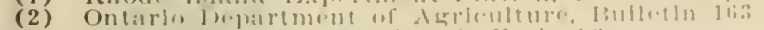

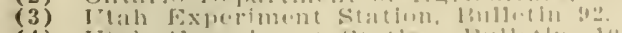

(4) ['ta], bixperiment sitatlon, J311tull1, 102

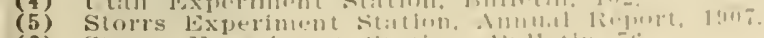

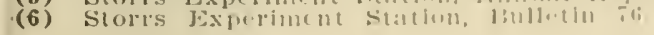


weight of the developing embryo. Under setting hens the amount increased toward the latter part of the hatch to from 50 to 60 parts per 10,000 parts of air, and in commercial incubators to from 30 to 50 parts in 10,000 parts of air. Good results were obtained when the carbon dioxide did not exceed 60 parts in 10,000 parts of air which, according to these authors, approximates the amount found in natural incubation. The effect of carbon dioxide was slight until a maximum of 150 parts was reached; as the amount rose above that point there was a marked decrease in the number of chicks hatched. Atwood and IVeakley (7) showed that fertile eggs gave off about 10 grams of carbon dioxide during the 21 days of incubation and that the amount increased rapidly toward the latter part of the period.

In this connection it may be well to observe that the carbon dioxide given off is the result of an oxidation process in which oxygen from the air combines with some of the carbon of the egg, the result being that although we speak of the loss of carbon dioxide yet the actual loss of egg substance is only about 27.3 percent of the total weight of the carbon dioxide measured, the balance of the weight being oxygen.

The amount of carbon dioxide per 10,000 parts of the air in air taken from under hens or from incubators would be influenced by the rapidity of circulation of the air about the eggs, consequently all of the investigations mentioned, except the last, present few definite data as to the amount of this gas given off by the developing embryos.

\section{METHODS OF INVESTIGATION}

In the present work it was felt that each egg should be incubated by itself because when several eggs are incubated together the total amount of carbon dioxide given off might be influenced by the lacki of fertility of certain eggs or by the weakness or death of embryos. Also it was clesired to study the amount of carbon dioxide given! off at various periods of incubation as well as various factors affecting: the vigor of the embryos, for which purpose the results from mass. incubation would be entirely inapplicable.

Each egg was incubated by itself in a glass tube (see Figure 1: on cover). One end of this tube was connected to an air supply from which all traces of carbon dioxide had been removed, and the other

(7) Journal of the American Association of Instructors and Investigators in. Poultry Husbandry. VoL. I, No. 4, Dp. $26-28$ (1915). 


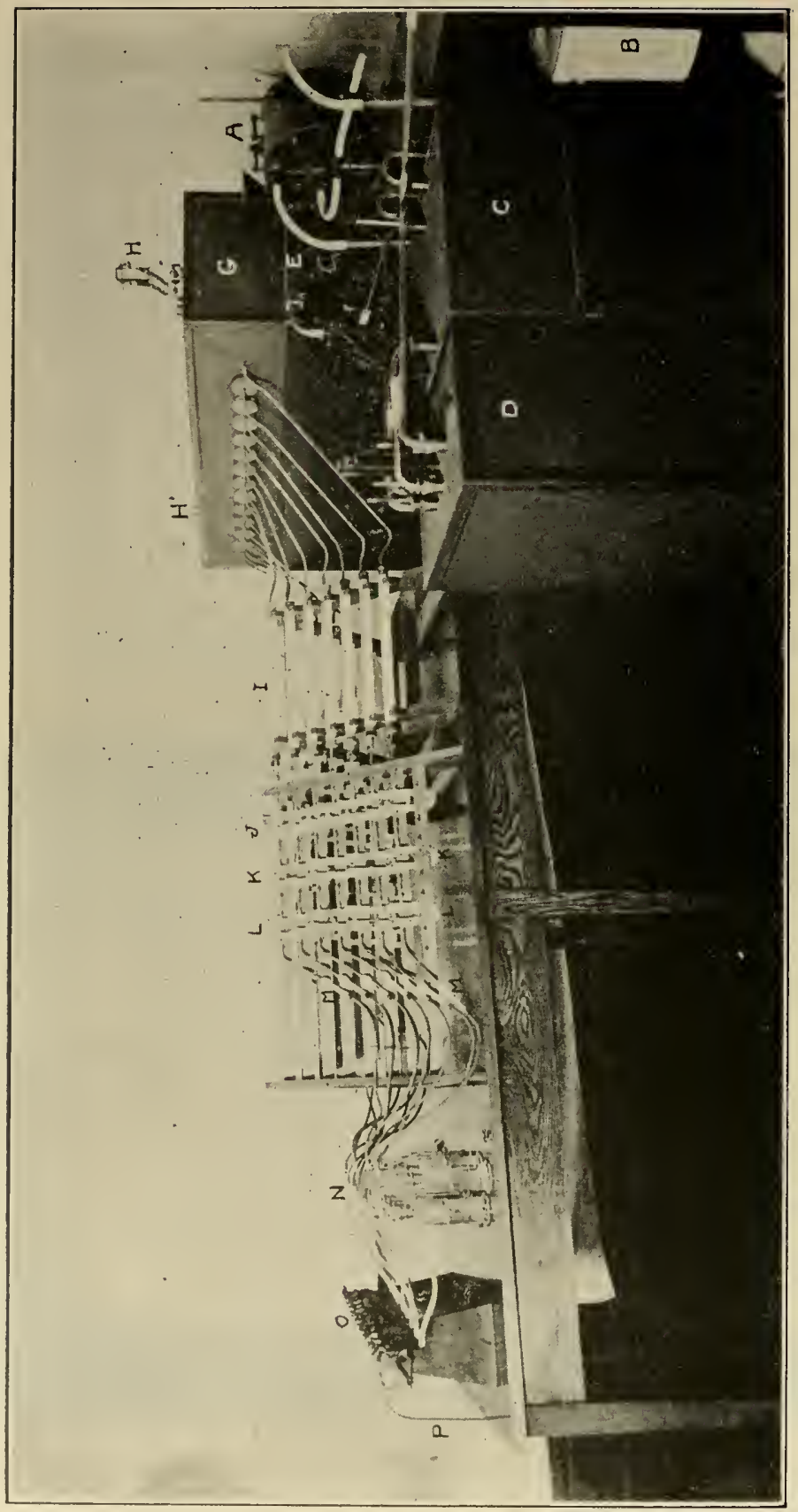

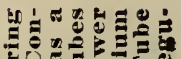

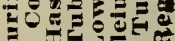
T. तथ 勿

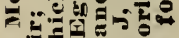

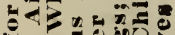
4.

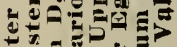

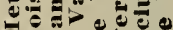

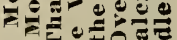
$<0$ ज पे में

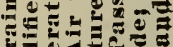

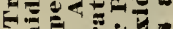

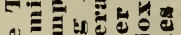
$\pm 0$

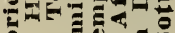

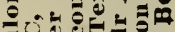
30

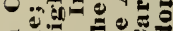
폴 E. 을 a ऽ于5 Fo Eह 40

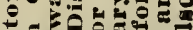
J 푸 $x=x-3$ 引

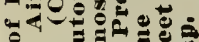
Q

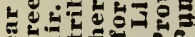
质 × $x$

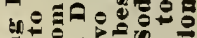

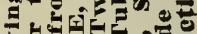
E ด कี

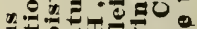

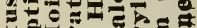

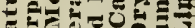
일

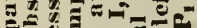
루 y $<$ 단 $\because$ m. 政 $0<0$ 以

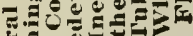
U日

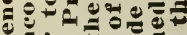

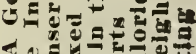

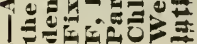
$\Leftrightarrow$ i) 


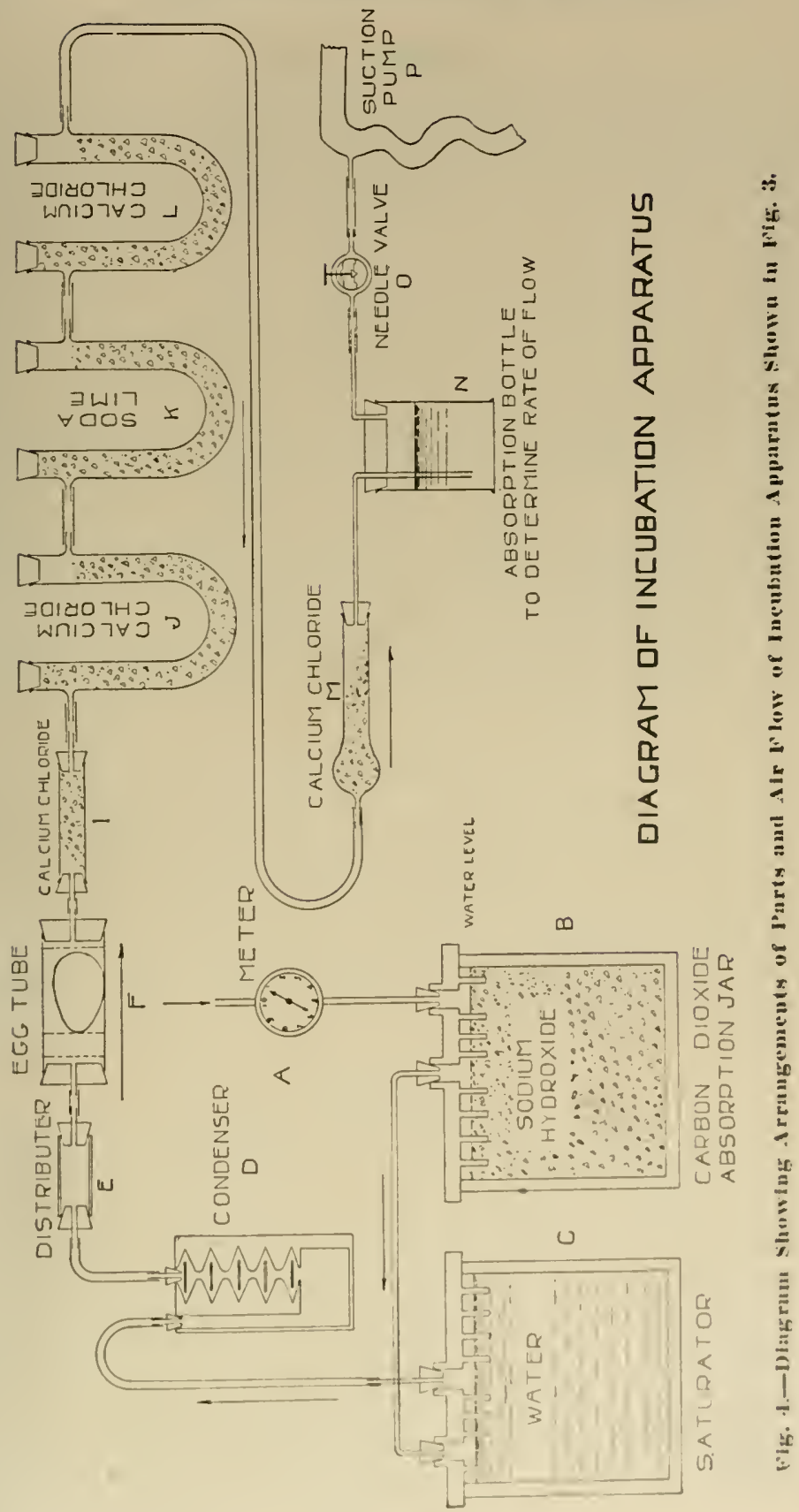




\section{Incubators Used}

Two incubators were used: one a Bausch and Lomb constanttemperature bacteriological incubator modified so as to permit the use of the egg tubes and necessary air distributors; the other a specially constructed incubator in which the top temperature of the egg could be controlled independently of the bottom temperature. The latter was, in effect, two incubators, one superimposed upon the other and provided with independent thermostats.

The egg tubes were about $5 \mathrm{~cm}$. in diameter and $25 \mathrm{~cm}$. long, closed with No. 11 rubber stoppers having glass tubes in the center sufficiently long to extend through the walls of the incubator. Cheese cloth diaphragms were used in each end of the egg tubes to keep the eggs near the center and to break up any direct air currents. The glass tubes extending through the stopper and the sides of the incubator were connected with the air supply and the calcium chloride train by rubber tubes so as to permit the turning of the eggs by merely turning the glass tubing.

\section{Air Circulation}

The total amount of air used for each set of eggs was measured by a wet meter and the amount passing through each egg tube was regulated by a needle valve on the suction end, the rapidity of circulation being observed through the use of absorption bottles. The air was sucked through by a vacuum pump which maintained a uniform suction at all times.

\section{Humidity}

After the air was freed from carbon dioxide it was passed through a series of jars similar to those used for the removal of the carbon dioxide, but filled with water. This could be held at any given temperature by an electric heater and thermostat. By this means the air could be saturated with moisture at any desired temperature above room tem, rerature. Then it was passed through a constant-temperature condenser of special design which consisted of a series of flattened copper bulbs provided with baffle plates and the whole immersed in water which could be held at a uniform temperature, thus permitting the humidity to be reduced to any desired point. 


\section{Measuring the Carbon Dioxide Given Off}

After the air, which had been freed from carbon dioxide, had been drawn through the various egg tubes each containing an egg it was passed through two calcium chloride tubes, the first being a horizontal tube about two feet long which removed the greater part of the moisture, and the second a " $U$ " tube which removed the remainder. These tubes before being used were saturated with carbon dioxide. The air then passed through a " $U$ " tube filled with moist soda lime, and a calcium chloride " $U$ " tube to catch the moisture given off by the soda lime. Also, a calcium chloride tube was used as an insurance against any moisture creeping back from the absorption bottles. Figure 3 shows the general arrangement of the tubes.

The soda lime and calcium chloride tube which followed it were weighed together every 24 hours, using a counterpoise of the same sized tubes partially filled. One extra set of calcium chloride and soda lime tubes was provided. When the tubes in Line 1 were removed for weighing, the extra tubes were immediately placed in the line so that there would be as little interruption in the circulation of air through the system as possible. The tubes just removed and weighed were then placed in Line 2 and so on.

\section{Checking the Determinations}

Two egg tubes were allowed to remain empty during each hatch and the weighings were made for carbon dioxide as in the other cases. This was done so as to be certain that the apparatus was working satisfactorily.

\section{Management of Eggs}

In all instances incubation was started on the day following that on which the eggs were laid. The eggs were turned at least twice each day by turning the glass tubes in which they were contained, and an effort was made to maintain the humidity and temperature as nearly normal as possible. For the purpose of reading the temperature a thermometer was inserted in one of the vacant egr tubes at approximately the height of an egg. The fluctuations in temperature were never greater than $1 / 2$ degree Fahr. The eggs remained within their respective tubes from the beginning of incubation nutil the tubes were opened to remove the chicks. 
It may be well to mention here that the authors have been engaged for some years in the study of the vigor of chick embryos as measured by the carbon dioxide which they throw off during the period of incubation and the data presented in the following tables have been selected from the material accumulated in that investigation. As a consequence, the eggs studied have been produced under somewhat varying conditions but it is felt that these factors are of negligible importance as affecting the value of these data which are presented for the purpose of affording a basis for the intelligent ventilation of incubators.

Only eggs laid by Single Comb White Leghorn fowls were incubated, and the data represent the results from: 63 eggs that hatched normal chicks.

\section{AMOUNT OF CARBON DIOXIDE GIVEN OFF PER EGG}

Table I gives the average amount of carbon dioxide, in grams, given off each day during incubation, together with the probableerror and the standard deviation.

TABILE I.-Amount of Carbon Dioxide Given Off By Eggs During. Incubation.

\begin{tabular}{|c|c|c|}
\hline $\begin{array}{l}\text { Day of } \\
\text { Incubation }\end{array}$ & $\begin{array}{l}\text { Grams of } \\
\text { Carbon Dioxide }\end{array}$ & $\begin{array}{l}\text { Standard } \\
\text { Deviation }\end{array}$ \\
\hline First .. & 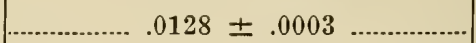 & .0031 \\
\hline Second & $\ldots \ldots \ldots \ldots \ldots \ldots . .0085 \pm .0002 \ldots \ldots \ldots \ldots \ldots \ldots$ & .0028 \\
\hline Third .. & $00119 \pm .0002 \ldots \ldots$ & .0025 \\
\hline Fourth & $.0210 \pm .0003$ & .0034 \\
\hline Fifth & 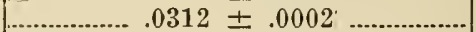 & .0020 \\
\hline Sixth & 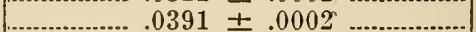 & .0019 \\
\hline Seventh ..... & $.0513 \pm .0004$ & .0050 \\
\hline Eighth & $.0681 \pm .0005 \ldots \ldots \ldots$ & .0059 \\
\hline Ninth & $.0916 \mp .0008$ & .0090 \\
\hline 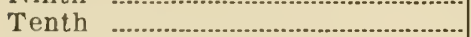 & $.001 \pm .0012$ & .0147 \\
\hline Eleventh ............. & $.1758 \pm .0028$ & .0335 \\
\hline Twelfth .... & $.2488 \mp .0026$ & .0312 \\
\hline Thirteenth & $.3377 \pm .0036$ & .0424 \\
\hline (n) & $4580 \mp .0051$ & .0606 \\
\hline Fifteenth & $\ldots . .05739 \pm . . . \ldots \ldots \ldots$ & .0671 \\
\hline Sixteenth & $\ldots . .6706 \pm .0047 \ldots$ & .0553 \\
\hline Seventeenth & .7277 士 .0057 & .0667 \\
\hline Eighteenth. & $.7563 \pm .004 . \ldots \ldots \ldots$ & .0488 \\
\hline Nineteenth & $.7801 \mp .0065$ & .0766 \\
\hline Twentieth & $1.0036 \pm .0171$ & .2016 \\
\hline Twenty-first & $1.4260 \pm .0216$ & .2545 \\
\hline
\end{tabular}


Table I shows that beginning on the second day the amount of carbon dioxide given off increased daily until the end of the period. It seems probable that the amount shown for the first day includes carbon dioxide originally dissolved in the egg substance and which escaped during the first twenty-four hours after the eggs were surrounded by carbon-dioxide-free air due to the lowering of the vapor pressure. In any event the amount so given off is small and of no practical significance.

From the beginning of incubation to the tenth day the daily increase in the amount of carbon dioxide given off was small, but after that half-way period in the development of the embryo was. passed, the daily increase was very great. The increase from the nineteenth to the twentieth day is practically equal to the total amount given off during the first eight days, and the increase from. the twentieth to the twenty-first day is roughly equal to all the carbon dioxide given off during the first half of the hatch.

Figure 5 shows graphically the average amount of carbon dioxide. in grams, given off per egg per day during incubation.

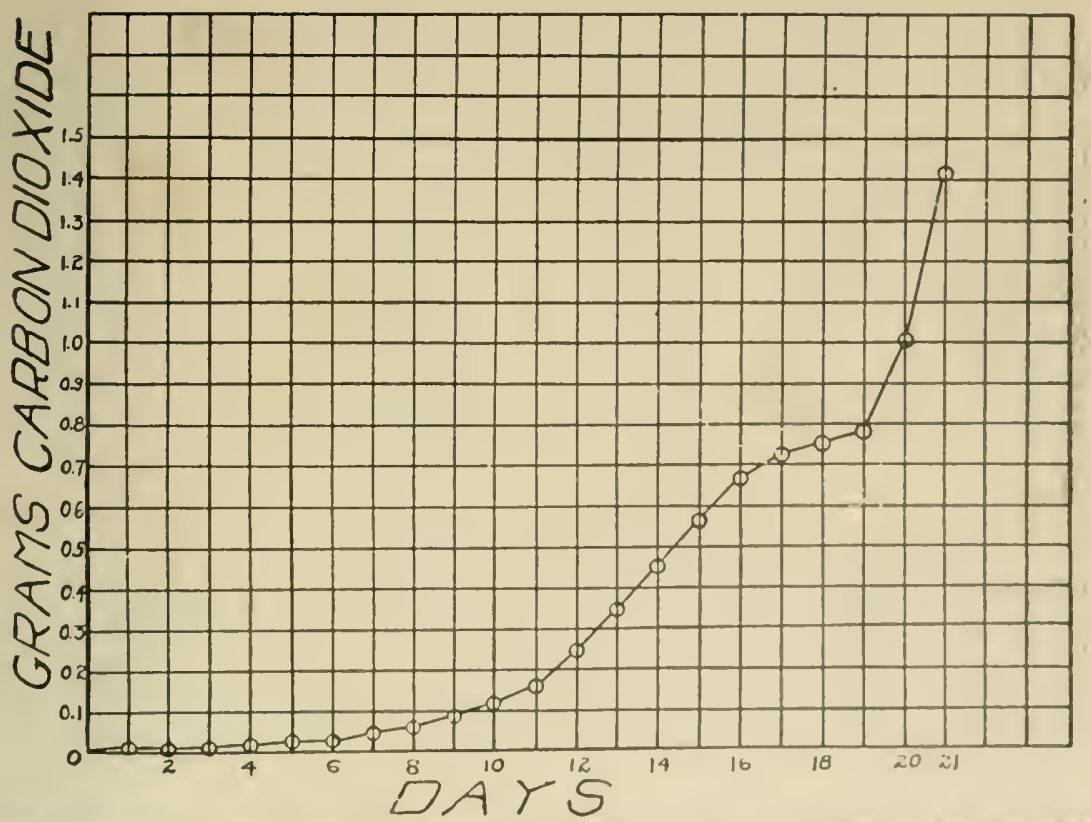

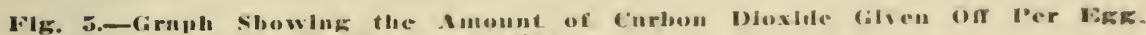
p'er IDy linring Lucubuton. 
It is apparent from Figure 5 that the circulation of air through the incubator chamber for the purpose of removing the carbon dioxide that is generated may be greatly restricted up to the tenth day. By thus restricting the circulation, the moisture present in the eggs may be conserved during the first part of the hatch. Later, however, the oxidation process is greatly accelerated and the ventilation should be increased correspondingly. Especially during the last two days of incubation should the eggs be given a liberal supply of air.

\section{AMOUNT OF AIR REQUIRED FOR ONE HUNDRED EGGS DURING INCUBATION}

As already stated, Lamson and Edmond found that the air under setting hens toward the end of the hatch contained from 50 to 60 parts of carbon dioxide in 10,000 parts of air. Using the smaller value and the weights of carbon dioxide shown in Table I, the number of cubic feet of air required daily per hundred eggs is shown in Table II.

TABLE II.-Number of Cubic Feet of Air Required Daily per One Hundred Eggs to Maintain a Carbon-Dioxide Content of Fifty Parts in 10,000 Parts of Air.

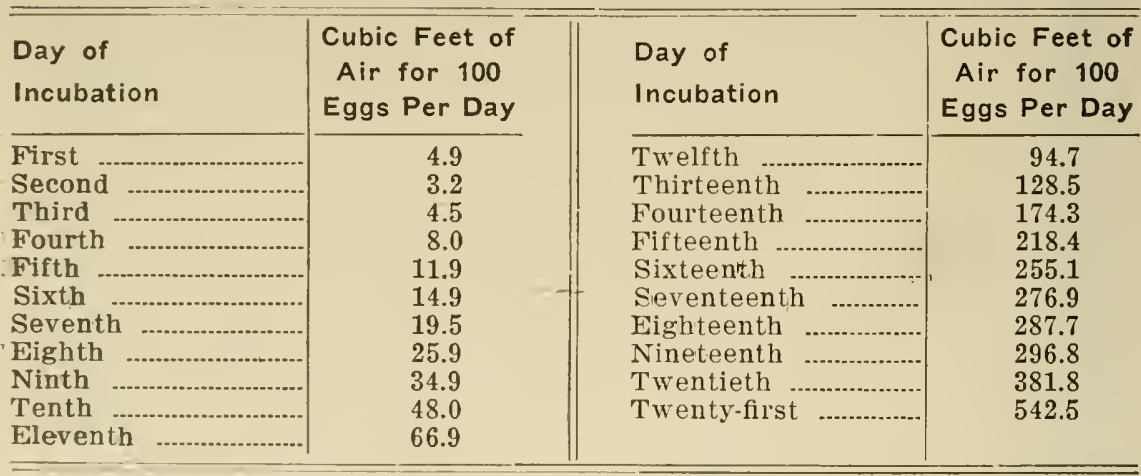

It should be understood that the authors consider Table II largely as suggestive. The comparative values as given are correct, but it may be found that it is not necessary to ventilate so freely as to maintain only 50 parts of carbon dioxide in 10,000 parts of air. It should also be pointed out that the table is based on the assumption of a uniform percentage of carbon dioxide in the air of the incubator from start to finish, but it is possible that the embryos can tolerate a greater percentage of carbon dioxide in the air at one stage of 
development than at another. Also in any commercial incubator some of the eggs are certain to be infertile or to have weak germs, which would reduce the amount of air required.

\section{FACTORS AFFECTING THE AMOUNT OF CARBON DI- OXIDE GIVEN OFF BY EGGS DURING INCUBATION}

\section{Infertility}

Infertile eggs give off little carbon dioxide. As an example, the following record is given of an infertile egg weighing 58.939 grams placed in the incubator December 22, 1914.

\begin{tabular}{|c|c|c|c|}
\hline $\begin{array}{l}\text { Day of } \\
\text { Incubation } \\
\text { First }\end{array}$ & $\begin{array}{l}\text { Loss of Carbon } \\
\text { Dioxide in Grams }\end{array}$ & $\begin{array}{c}\text { Day of } \\
\text { Incubation } \\
\text { Fifth }\end{array}$ & $\begin{array}{l}\text { Loss of Carbon } \\
\text { Dioxide in Grams }\end{array}$ \\
\hline Second & .0064 & Sixth & .0034 \\
\hline Third & ……........ & Seventh & .0029 \\
\hline Fourth & 0040 & Eighth & .0008 \\
\hline
\end{tabular}

\section{Weak Germs}

Eggs with weak germs may give off nearly a normal amount of carbon dioxide for a few days. The amount then decreases rapidly. As an example the following record may be taken as typical. Weight of egg was 60.976 grams when incubation started May 16, 1914.

$\begin{gathered}\text { Day of } \\ \text { Incubation } \\ \text { First }\end{gathered}$
$\begin{gathered}\text { Loss of Carbon } \\ \text { Dioxide in Grams }\end{gathered}$ $\begin{gathered}\begin{array}{c}\text { Day of } \\ \text { Incubation } \\ \text { Second }\end{array} \\ \text { Thenth }\end{gathered}$

The embryo died during the tenth day.

Weight of the Eggs

Benjamin ${ }^{1}$ has shown that other things being equal the larger the egg, the larger and more vigorous the chick hatched therefrom. Accepting this, one would naturally assume that large eggs would throw off more carbon dioxide than small eggs. To study this problem Table III has been arranged. The same data that were used in the preparation of Table I are used here. 


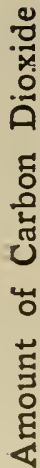

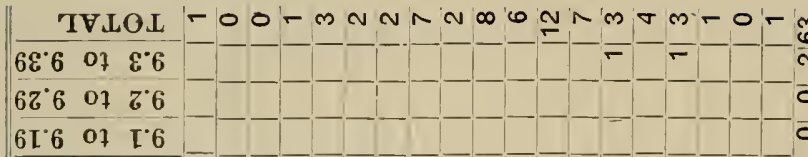

$\begin{array}{lll}60^{\circ} 6 & 07 & 0.6\end{array}$ 
The correlation is positive and significant and shows that the larger eggs generally give off more carbon dioxide than do the smaller ones. This is in harmony with Benjamin's results, and it would consequently seem that the practice of selecting the larger eggs for incubation tends toward the maintenance of size and vigor of offspring.

\section{CONCLUSIONS}

1.-The amount of carbon dioxide thrown off by eggs during the incubating process is relatively small during the first half of the hatch. Consequently the ventilation may be materially restricted during the first ten days, if this should be desirable in order to conserve the moisture in the eggs.

$?$ the last half of the period of incubation the amount of carbon dioxide given off increases rapidly. Therefore the amount of air passing through the incubating chamber should be increased correspondingly. During the last two days in particular the supply of air should be ample. 

